\title{
Az évjárat és a genotípus hatása különbözô típusú silókukorica hibridek morfológiai és agronómiai tulajdonságaira
}

\author{
TÓTHNÉ ZSUBORI ZSUZSANNA-PÓK ISTVÁN-HEGYI ZSUZSANNA \\ MTA Mezőgazdasági Kutatóintézete, Martonvásár
}

\section{Összefoglalás}

A silókukorica nemesítésben a leafy típusú hibridek egy új irányvonalat képviselnek. Ezekben a hibridekben a megnövekedett csố feletti levélszám nem csak a szárazanyag produkciót növeli, de a levelekben képzôdött és raktározott nagy mennyiségú szénhidrát a szilázsnak jobb beltartalmi minôséget biztosít. A témában külföldön már több tanulmány is született, Magyarországon azonban még kevés adatot publikáltak.

Munkánkban célul tưztük ki a genotípus és az évjárat hatásának vizsgálatát 6 különbözô típusú, leafy és nem-leafy silókukorica hibridnél, 4 éven keresztül (2002-2005 között), elsôsorban a növénymagasság és csôeredési magasság, a levélszám, a zöld- ill. szárazanyag termés tekintetében.

Az eredményekből megállapítható, hogy a két leafy hibrid cső feletti levélszáma $(8,00 ; 9,35)$ jóval magasabb volt a többi hibrid átlagánál (5,56 az évek átlagában). Ez a tulajdonság szoros negatív korrelációban $(r=-0,7346)$ állt a csóeredés arányával, amely egy genetikailag erôsen meghatározott tulajdonság, az évjárathatás kevésbé befolyásolta. A leafy hibrideknél a fốcsố jóval alacsonyabban helyezkedett el, a növények magassága azonban a többi hibridéhez hasonló volt. A csôeredés aránya a növénymagassághoz a leafy hibridek esetében 0,36, a többi hibridnél 0,41 és 0,45 között változott (az évek átlagában). A csapadékosabb évjáratokban a hibridek magasabbak voltak és egyedi zöldtömegük nagyobb volt, mint a száraz évben.

Kulcsszavak: silókukorica, leafy, zöldtömeg, genotípus, évjárat 


\title{
Year and genotype effect on morphological and agronomical traits of different silage maize hybrids
}

\author{
ZS. TÓTHNÉ ZSUBORI-I. PÓK-ZS. HEGYI
}

Agricultural Research Institute of the Hungarian Academy of Sciences, Martonvásár

\section{Summary}

Leafy hybrids represent a new direction in the breeding of silage maize. Not only does the increased number of leaves above the ear in these hybrids lead to an increase in dry matter production, but the large quantity of carbohydrates formed and stored in the leaves results in silage with better chemical quality. Many papers have been published abroad on this subject, but few data have been reported in Hungary.

The present work aimed to examine the effect of genotype and year on six leafy and non-leafy silage maize hybrids over a period of four years (2002-2005), with special emphasis on the plant height, ear attachment height, leaf number, and fresh and dry matter yield.

The results showed that the number of leaves above the ear was much higher for the two leafy hybrids ( 8.00 and 9.35) that the average of the other hybrids (5.56, averaged over the years). This trait was in close negative correlation $(r=-0.7346)$ with the ratio of ear attachment height to total plant height, a trait with strong genetic determination, little influenced by the year. In leafy hybrids the main ear was located far lower down, but the total plant height was similar to that of the other hybrids. The ratio of ear attachment height to plant height was 0.36 for the leafy hybrids, but ranged from 0.41 to 0.45 for the other hybrids (averaged over the years). In wetter years the hybrids were taller and had greater green mass per plant than in the dry year.

Key words: silage maize, leafy, green mass, genotype, year

\section{Bevezetés és irodalmi áttekintés}

A silókukorica termesztés és a silózás technikájának kidolgozása hazánkban közel másfél évszázados múltra tekint vissza. Elterjedésének fố oka az, hogy a 
teljes föld feletti kukoricanövény hasznosításával egységnyi vetésterületrôl sokkal több tápanyagot takaríthatunk be, mint ha csak a szemtermést hasznosítjuk. A teljes kukoricanövény nagyjából másfélszer annyi tápanyagot tartalmaz, mint a szem (Menyhért 1985).

A betakarítási idő erôsen befolyásolja a silókukorica végsô emészthetőségét és energiahozamát. A silóérettség állapotát, amikor a szemtelítódés már befejeződött, de a növény még zöld, 30-35\% szárazanyag tartalomnál éri el a kukorica (Weissbach és Auerbach 1999). A silókukorica betakarítása azonban 58\% nedvességtartalomig (42\% szárazanyag) még különösebb veszteség nélkül, a maximális termés és hektáronkénti tejhozam 95\%-ának fenntartásával elvégezhető (Darby és Lauer 2002). Józsa (1981) szerint a 35-40\%-os szárazanyag tartalomnál betakarított silókukorica esetében a csố részaránya a teljes növényi szárazanyag 55-65\%-a is lehet, ami nagyon jónak mondható. Az ilyenkor betakarított kukorica takarmányértéke is jobb, mint a korábban betakarítottaké, illetve ez a szárazanyag tartalom szükséges a szilázs megfelelő erjedéséhez is.

Carter et al. (1991) foglalta össze tömören a jó silóhibridtôl elvárt tulajdonságokat: nagy szárazanyag termés, magas fehérjetartalom, magas energiatartalom, jó emészthetôség, nagy felvevôképesség (alacsony rosttartalom), és optimális betakarításkori szárazanyag tartalom a megfelelő erjedéshez és tároláshoz.

A silókukorica minôsége szempontjából tehát a hektáronkénti minél nagyobb zöld- illetve szárazanyag termés mellett kiemelkedô fontosságú a szilázs beltartalma és emészthetôsége. A világon évek óta folynak kísérletek ezen minőségi paraméterek javítására különbözô gének bevonásával, ilyenek a $B M R$ (Brown Midrib = barna levélerú), a $w x$ (waxy = viaszos), az $o_{2}$ (opaque = opálos szemú), a floury-2 (lisztes), valamint a magas olajtartalmú hibridek, melyeknél lényeges minôségjavulást értek el. Gyakorlati elterjedésük azonban a gyengébb átlagtermés és az egyéb agronómiai tulajdonságokban jelentkezô negatív hatások miatt nem volt jelentős (Cox és Cherney 2001). Az lfy 1 nevú gén használata azonban a silókukorica esetében (ún. leafy hibridek) hosszútávon is elônyösnek bizonyult. Ezt a gént $R$. C. Muirhead fedezte fel, de elôször Shaver (1983) írt róla részletesebben, ismertetve a gén eredetét, öröklődését, és a kukorica morfológiájára illetve termésére gyakorolt, legtöbbször pozitív hatásait.

A leafy hibridek legfőbb jellemzője, hogy több levéllel rendelkeznek, mint 
a normál hibridek. Elsôsorban a csô feletti levelek száma nagyobb, de emellett a csốeredési magasság is alacsonyabb, rövidebbek az internódiumok, a csô alatti szárrészben több lignin található, és nagyobb a terméspotenciáljuk is. A nagyobb csố feletti levélszám nagyobb asszimiláló levélfelületet jelent, a növény nagyobb hatékonysággal tudja megkötni a fotoszintézishez szükséges fényenergiát, így több tápanyag termelődik a levelekben (Dwyer et al. 1995). Ennek a termésre és a szemek minóségére gyakorolt pozitív hatásairól több szerzố is beszámolt (Stewart és Dwyer 1993, Begna et al. 2001, Modarres et al. 1997, Dijak et al. 1999). A levelek teljes növényi szárazanyagon belüli nagyobb részaránya és a csố feletti levelek nagyobb szénhidrát tartalma (Andrews et al. 2000) kedvezôen befolyásolja a szilázs minôségét és emészthetôségét. Magyar szerzók (Pintér et al. 1988) kísérletei is bizonyítják, hogy az egész növény energiakoncentrációját 35\% harvest index felett nem a szem arány, hanem a vegetatív részek minôségi tulajdonságai határozzák meg. Tehát a nagyobb csố feletti levélfelület jobb minőségú szilázst eredményez.

A témában külföldön (elsősorban Kanadában, az Egyesült Államokban és Franciaországban) már több tanulmány is született, Magyarországon azonban még kevés adatot publikáltak.

Munkánkban célul túztük ki a genotípus és az évjárat hatásának vizsgálatát különbözố típusú, leafy és nem-leafy silókukorica hibrideknél, elsôsorban a növénymagasság és csóeredési magasság, a levélszám, a zöld- ill. szárazanyag termés tekintetében.

\section{Anyag és módszer}

Kísérletünkben 6 martonvásári nemesítésú, leafy és nem-leafy silókukorica hibridet vizsgáltunk Martonvásáron 4 éven keresztül (2002-2005), öntözött körülmények között (1. táblázat). A vetés 80000 tô/ha-nak megfeleló magmennyiséggel történt, 4 ismétléses, véletlen blokk elrendezésú kísérletben. Minden évben azonos agrotechnikát alkalmaztunk.

Az időjárás a négy évben igen eltérôen alakult, száraz meleg és húvös csapadékos évjárat egyaránt előfordult. A 2002-es, átlagosnak mondható év után a 2003-as jóval melegebb és szárazabb volt, légköri aszály is sújtotta a növényeket (az éves csapadék mindössze $367 \mathrm{~mm}$ volt, és augusztusban 25 hóségnapot regisztráltunk). Ezután pedig két húvös, csapadékos év következett. 2004-ben szinte nem is volt hôségnap (csak kettő júliusban), 2005-ben pedig a 2003. évi 
csapadék duplája esett, melyből jelentős mennyiség augusztusban hullott (185,9 $\mathrm{mm}$ ). A tenyészidő alatti hőösszeg is az első két évben volt nagyobb, augusztusig 1405 és 1486, míg a második két évben ez az érték csak 1206 és 1241 volt (Martonvásáron mért adatok alapján).

1. táblázat. A kísérletben szereplö hibridek

\begin{tabular}{clcl}
\hline $\begin{array}{c}\text { Sorszám } \\
(1)\end{array}$ & \multicolumn{1}{c}{$\begin{array}{c}\text { Hibrid } \\
(2)\end{array}$} & $\begin{array}{c}\text { Tenyészidő } \\
(3)\end{array}$ & \multicolumn{1}{c}{$\begin{array}{c}\text { Típus } \\
(4)\end{array}$} \\
\hline 1 & Limasil & FAO 380 & leafy \\
2 & Mv NK333 & FAO 390 & nem-leafy (5) \\
3 & Mv 434 & FAO 440 & nem-leafy (5) \\
4 & Mv 448 & FAO 450 & nem-leafy (5) \\
5 & Mv 437 & FAO 480 & nem-leafy (5) \\
6 & Kámasil & FAO 510 & leafy \\
\hline
\end{tabular}

Table 1. Hybrids tested in the experiment. (1) No., (2) Hybrid, (3) Vegetation period, (4) Type, (5) Non-leafy.

Ezek az évjáratbeli különbségek a növényállomány fenotípusán és a mért tulajdonságokban is megnyilvánultak.

Kísérletünkben megmértük a növénymagasságot (a talajtól a címer csúcsáig), a fốcsôeredési magasságot, a csôeredési magasság arányát a növénymagassághoz, a levélszámot a cső alatt, a cső felett, illetve összesen, valamint a növények egyedi zöldtömegét és szárazanyag produkcióját, melybôl a tôszámmal kalkulálva következtethetünk a hektáronkénti szárazanyag termésre. Emellett vizsgáltuk a kelést (vetéstôl a kelésig eltelt napok száma), a kezdeti fejlôdést, a hímvirágzás és a nôvirágzás idejét, valamint a proterandriát.

Fontos célkitúzésünk volt az egyes tulajdonságok közötti összefüggések vizsgálata is, különös tekintettel a leafy hibridekre, hogy megállapítsuk, a megnövekedett csố feletti levélszám mennyiben befolyásolja az egyéb morfológiai és agronómiai tulajdonságokat.

A kapott adatokat Agrobase statisztikai programmal elemeztük, varianciaanalízist és korrelációszámítást végeztünk Sváb (1967) módszere alapján. 


\section{Eredmények}

Az évjáratokban tapasztalható különbség egyes tulajdonságok esetében (kelés, zöld- ill. száraz tömeg) erôteljesen megnyilvánult, míg más tulajdonságoknál (csôeredés aránya a növénymagassághoz) a genotípusok közötti különbség volt a jelentôsebb. A hímvirágzás, nôvirágzás és a szárazanyag tartalom esetében pedig a genotípus és az évjárat kölcsönhatása is erôsen szignifikáns volt (2. táblázat).

A közölt korrelációs együtthatók (r) értékei minden esetben p=0.1\%-os szinten szignifikánsak, kivéve, ahol ezt külön jeleztük.

\section{Kelési idó és kezdeti fejlôdés}

A kelés (vetéstől eltelt napok számában kifejezve) az egyes évjáratokon belül nagyjából egyidőben történt, de az évek között nagy különbségek voltak. 2003-ban 8-9, 2004-ben pedig 14 nap telt el a vetéstől a kelésig. 2002-ben és 2004-ben az egyes genotípusok között nem volt különbség, mind ugyanazon a napon keltek ki.

A kezdeti fejlődés esetében már az évjáratok, illetve az egyes genotípusok között is volt különbség, de a kettő kölcsönhatása nem volt szignifikáns. 2002-ben mértük a leggyengébb értékeket, 2005-ben pedig a legjobbakat.

A kezdeti fejlődés értékei közepes pozitív korrelációt mutattak a csőeredési magassággal $(r=0,4243)$ és a csố alatti levélszámmal $(r=0,4783)$.

\section{Hímvirágzás, nôvirágzás, proterandria}

A hímvirágzás és a nôvirágzás esetében a genotípus, az évjárat és a kettő kölcsönhatása is erôsen szignifikáns volt $(\mathrm{p}<0,1 \%)$. A legkorábban virágzó hibrid az Mv NK 333 volt, kivéve 2005-ben (Mv 448), és a legkésőbb virágzó két hibrid is ugyanaz (Mv 437, Kámasil) volt mindkét évben. A többi hibrid sorrendje változó volt. A hímvirágzás és a nôvirágzás között igen szoros pozitív korreláció volt megfigyelhetô $(r=0,9670)$.

A proterandria esetében a hibridek sorrendje már nem volt ilyen következetes. Míg pl. 2004-ben a nóvirágzás minden esetben megelőzte a hímvirágzást, addig 2005-ben ez épp fordítva történt, tehát a proterandria erôsen évjárat-függô. Emellett a genotípus is szignifikánsan befolyásolta. 
2. táblázat. Genotípus, év és genotípus×év hatásának szignifikancia szintjei az egyes tulajdonságok esetében

\begin{tabular}{|c|c|c|c|}
\hline $\begin{array}{c}\text { Tulajdonság } \\
\text { (1) }\end{array}$ & $\begin{array}{l}\text { MQ genotípus } \\
(2)\end{array}$ & $\begin{array}{l}\text { MQ év } \\
\text { (3) }\end{array}$ & $\begin{array}{c}\text { MQ } \\
\text { genotípus } \times \text { év } \\
(4)\end{array}$ \\
\hline Kelési idő (5) & $1,167 *$ & $124,917 * * *$ & 0,550 N.S. \\
\hline Kezdeti fejlődés (6) & $8,342 * *$ & $13,125 * * *$ & 1,592 N.S. \\
\hline Hímvirágzás (7) & $209,769 * * *$ & $962,927 * * *$ & $6,535 * * *$ \\
\hline Nôvirágzás (8) & $148,460 * * *$ & $660,483 * * *$ & $5,299 * *$ \\
\hline Proterandria (9) & $10,867 * * *$ & $42,792 * * *$ & 2,783 * \\
\hline Növénymagasság (10) & $4334,917 * * *$ & $13730,252 * * *$ & 158,855 N.S. \\
\hline Csőeredési magasság (11) & $1565,978 * * *$ & $2294,173 * * *$ & 82,166 N.S. \\
\hline $\begin{array}{l}\text { Csốeredés aránya a } \\
\text { növénymagassághoz (12) }\end{array}$ & $0,022 * * *$ & 0,001 N.S. & 0,001 N.S. \\
\hline Csố alatti levélszám (13) & $3,605 * * *$ & $20,583 * * *$ & $0,623 * * *$ \\
\hline Csố feletti levélszám (14) & $47,405 * * *$ & $2,071 * * *$ & $0,524 *$ \\
\hline Összes levélszám (15) & $37,850 * * *$ & $14,050 * * *$ & $1,193 *$ \\
\hline Egyedi zöldtömeg (16) & 35812,930 * & $75360,777 * * *$ & 18100,426 N.S. \\
\hline $\begin{array}{l}\text { Egyedi szárazanyag } \\
\text { produkció (17) }\end{array}$ & $5301,067 * *$ & $8954,249 * * *$ & 803,938 N.S. \\
\hline Szárazanyag tartalom (18) & $48,659 * * *$ & $219,164 * * *$ & $43,684 * * *$ \\
\hline
\end{tabular}

$* * * \mathrm{p}=0,5 \%,{ }^{* *} \mathrm{p}=1 \%,{ }^{*} \mathrm{p}=5 \%$, N.S. nem szignifikáns (19)

Table 2. Significance levels of genotype, year and genotypexyear for the studied traits. (1) Trait, (2) MS for genotype, (3) MS for year, (4) MS for genotype $\times$ year, (5) Time of emergence, (6) Initial development, (7) Tasseling, (8) Silking, (9) Proterandry, (10) Plant height, (11) Ear attachment height, (12) Ratio of ear attachment height to plant height, (13) No. of leaves below the ear, (14) No. of leaves above the ear, (15) Total leaf number, (16) Green mass per plant, (17) Dry matter yield per plant, (18) Dry matter content, (19) Non-significant.

Növénymagasság, csốeredési magasság, csóeredés aránya a növénymagassághoz

A növénymagasságot és a csőeredési magasságot is szignifikánsan befolyásolta az évjárat és a genotípus, míg a kettô arányára csak a genotípusnak volt szignifikáns hatása.

A legalacsonyabb (Mv NK 333) és a legmagasabb (Mv 437) növények minden évben ugyanazok voltak. A csôeredési magasság is minden évben ugyanannál a hibridnél volt a legalacsonyabb (Limasil), illetve a legmagasabb (Mv 
437) (1. ábra). A két tulajdonság között szoros pozitív korrelációt találtunk ( $\mathrm{r}=$ $0,7295)$.

1. ábra. A hibridek növénymagasságának és csôeredési magasságának alakulása a négy évben

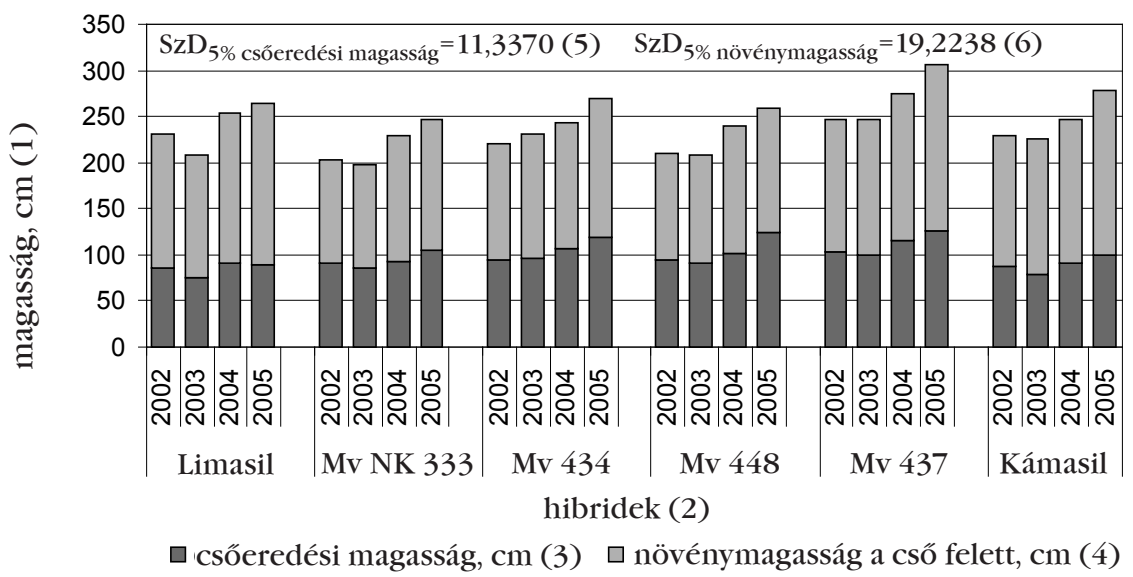

Figure 1. Plant height and ear attachment height of the hybrids in four years. (1) Height (cm), (2) Hybrids, (3) Ear attachment height (cm), (4) Plant height above the ear (cm), (5) $\mathrm{LSD}_{5 \%}$ for ear attachment height, (6) $\mathrm{LSD}_{5 \%}$ for plant height.

A csôeredés aránya a növénymagassághoz a leafy hibridek esetében jóval alacsonyabb volt: mindkettőnél 0,36 , a többi hibrid értékei pedig 0,41 és 0,45 között változtak az évek átlagában $\left(\mathrm{SzD}_{5 \%}=0,0162\right)$.

Csố alatti levélszám, csố feletti levélszám, összes levélszám

Mindhárom tulajdonság estében erôsen szignifikáns volt a genotípus és az évjárat hatása is.

A csố alatti levélszám tekintetében nem volt szignifikáns különbség a leafy és nem-leafy genotípusok között. Az évjárat és genotípus kölcsönhatása azonban szignifikáns volt.

A leafy és nem-leafy genotípusok közötti különbség a csố feletti levélszám tekintetében nyilvánult meg a legerôsebben. A legnagyobb különbség az Mv 448 és a Kámasil hibridek között volt (4,86 ill. 9,35 levél) (2. ábra).

A csố feletti levélszám és az összes levélszám között szoros pozitív korrelációt tapasztaltunk ( $r=0,8091)$, a csô alatti levélszámmal azonban nem volt szoros összefüggés. 
2. ábra. A hibridek csố alatti és csô feletti levélszámának alakulása a négy évben

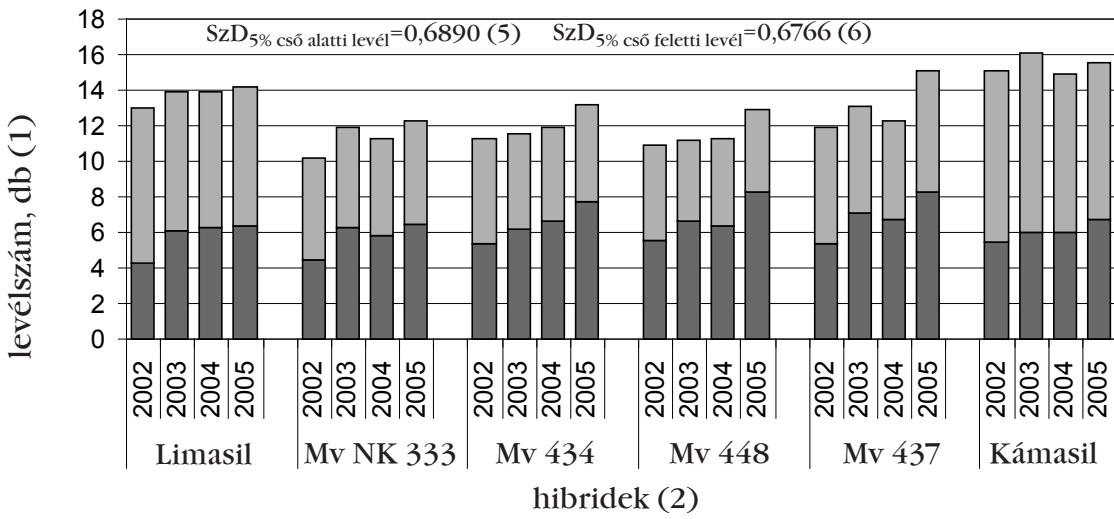

$\square$ csố alatti levél, db (3) घ csố feletti levél, db (4)

Figure 2. Leaf number below and above the ear of the hybrids in four years. (1) Leaf number, (2) Hybrids, (3) No. of leaves below the ear, (4) No. of leaves above the ear, (5) LSD 5\% $_{\text {for below-ear }}$ leaf number, (6) $\mathrm{LSD}_{5 \%}$ for above-ear leaf number.

Szoros negatív korrelációt találtunk a csô feletti levélszám és a csôeredés aránya között ( $\mathrm{r}=-0,7346)$, míg a csôeredési magassággal közepes volt a korreláció $(\mathrm{r}=-0,4343)$.

Az összes levélszám esetében is megfigyelhetó volt a különbség a leafy és nemleafy genotípusok között, de ez a különbség már nem volt olyan nagy. Mivel a cső feletti levélszámmal szoros volt a korreláció, ezért itt is találtunk összefüggést a csôeredés arányával $(r=-0,5532)$. Az összes levélszám ezen kívül a növénymagassággal is gyenge-közepes pozitív korrelációt mutatott $(\mathrm{r}=0,4002)$.

\section{Nedves tömeg, száraz tömeg, szárazanyag tartalom}

A szárazanyag produkciót a genotípus erősen befolyásolta. A nedves és a száraz tömeg között szoros pozitív korreláció volt $(\mathrm{r}=0,7481)$.

A szárazanyag tartalom a genotípusok és az évek között is erôsen változott, 28 és 43\% között. A szárazanyag tartalom és a nedves tömeg között közepes negatív korreláció volt $(\mathrm{r}=-0,4311)$.

A nedves tömeg a növénymagassággal is közepes korrelációt mutatott ( $\mathrm{r}=$ 0,4165). Vagyis a magasabb növények nagyobb zöldtömeget produkáltak.

A zöld- illetve száraztömeg gyenge korrelációt mutatott a csô feletti és az összes levélszámmal. A száraz tömeg (szárazanyag termés) és az összes levél- 
szám között gyenge volt a korreláció ( $\mathrm{r}=0,3121, \mathrm{p}=0,5 \%$-os szinten szignifikáns).

A hibridek egyedi zöldtömegének alakulását a 3. táblázat szemlélteti. Az adatokból kitúnik, hogy a csapadékos 2005-ös évben a hibridek zöldtömege jóval nagyobb volt, mint a többi évben. A legtöbb csô feletti levéllel rendelkezó Kámasil zöldtömege 2002-ben és 2005-ben enyhén meghaladta az átlagot, ez a különbség azonban nem volt statisztikailag igazolható.

3. táblázat. A hibridek egyedi zöldtömegének alakulása a négy évben (g/növény)

\begin{tabular}{lccccc}
\hline \multicolumn{1}{c}{$\begin{array}{c}\text { Hibridek } \\
(1)\end{array}$} & 2002 & 2003 & 2004 & 2005 & $\begin{array}{c}\text { Évek átlaga } \\
(2)\end{array}$ \\
\hline Limasil & 636,98 & 598,50 & 605,35 & 809,57 & 662,60 \\
Mv NK 333 & 602,13 & 737,61 & 680,85 & 793,69 & 703,57 \\
Mv 434 & 667,74 & 640,69 & 669,84 & 738,58 & 679,21 \\
Mv 448 & 629,91 & 739,80 & 787,87 & 625,34 & 695,73 \\
Mv 437 & 715,40 & 712,30 & 813,27 & 950,92 & 797,97 \\
Kámasil & 685,05 & 654,65 & 671,06 & 793,95 & 701,18 \\
\hline Hibridek átlaga (3) & 656,20 & 680,59 & 704,71 & 785,34 & 706,71 \\
\hline
\end{tabular}

$\mathrm{SzD}_{5 \% \text { genotípus }}=80,0378(4), \mathrm{SzD}_{5 \% \text { év }}=65,3506$ (5), $\mathrm{SzD}_{5 \% \text { genotípus×év }}=160,0757$ (6)

Table 3. Green mass per plant of the hybrids in four years (g per plant). (1) Hybrids, (2) Year mean, (3) Hybrid mean, (4) $\mathrm{LSD}_{5 \%}$ for genotype, (5) $\mathrm{LSD}_{5 \%}$ for year, (6) $\mathrm{LSD}_{5 \%}$ for genotype $\times$ year.

\section{Következtetések}

Az eredmények alapján megállapítottuk, hogy az évjárat által leginkább befolyásolt tulajdonságok a virágzási idő, a proterandria és a növényenkénti zöldtömeg voltak, legkevésbé pedig a csôeredés aránya a növénymagassághoz változott.

Általánosságban elmondható, hogy a hưvösebb, csapadékosabb évjáratokban a növények magasabbak voltak, és egyedi zöldtömegük nagyobb volt, mint az aszályos 2003-as évben, vagyis genetikai potenciáljuk jobban érvényesült. Ez alátámasztja Józsa (1981) megállapításait, miszerint vízhiányban a növények elmaradnak a növekedésben, és termésük is kevesebb.

A mintavételezés minden évben egységesen a virágzás után 40 nappal történt, ám az addig akkumulálódott hôösszeg eltérô volt, ezért a növények szárazanyag tartalma is változott az érés függvényében.

A csőeredés aránya a növénymagassághoz genetikailag erôsen determinált 
tulajdonságnak bizonyult, az évjárathatás kevésbé befolyásolta, mint a növénymagasság és a csôeredési magasság abszolút értékeit. A leafy hibridek esetében a csố jóval alacsonyabban helyezkedett el a teljes növénymagassághoz viszonyítva, ami a korábbi irodalmi adatokkal egyezik (Shaver 1983).

A leafy hibridek csó feletti levélszáma jóval több volt, mint a nem-leafy hibrideké, ahogy ezt más szerzók is megállapították (Shaver 1983, Dijak et al. 1999). Irodalmi adatok alapján (Dwyer et al. 1998) a több cső feletti levél nagyobb zöldtömeget eredményez, de kísérletünkben a különbség nem volt statisztikailag igazolható az adott hibridek esetében. Azóta több új, korszerú leafy hibridet állítottunk elő, melyeknél az újabb kísérleti eredmények már igazolták ezt az összefüggést, valamint a nagyobb levélfelület hatására képződött több tápanyag beltartalomra gyakorolt kedvezô hatásait is kimutatták (Hegyi et al. 2009).

Mindezek miatt a hagyományos silókukorica hibridek mellett a leafy hibrideknek is nagy szerepe lehet az állati takarmányok előállításában, jobb teljesítmények és hozamok elérésében, akár szélsôséges évjáratokban is.

\section{IRODALOM}

Andrews, C. J.-Dwyer, L. M.-Stewart, D. W.-Dugas, J. A.-Bonn, P.: 2000. Distribution of carbohydrate during grainfill in Leafy and normal maize hybrids. Canadian Journal of Plant Science. 80. 1: 87-95.

Begna, S. H.-Hamilton, R. I.-Dwyer, L. M.-Stewart, D. W.-Cloutier, D.-Assemat, L.Foroutan-pour, K.-Smith, D. L.: 2001. Morphology and yield response to weed pressure by corn hybrids differing in canopy architecture. European Journal of Agronomy. 14: 293-302.

Carter, P. R.-Coors, J. G.-Undersander, D. J.-Albrecht, K. A.-Shaver, R. D.: 1991. Corn hybrids for silage: an update. [In: Wilkinson, D. (ed.) Proc. of 46th Annual Corn and Sorghum Research Conference. Chicago. IL.] American Seed Trade Association. Washington D.C. 141-164.

Cox, W.J.-Cherney, D. J. R.: 2001. Influence of Brown Midrib, Leafy and Transgenic Hybrids on Corn Forage Production. Agronomy Journal. 93. 4: 790-796.

Darby, H. M.-Lauer, J. G.: 2002. Harvest date and hybrid influence on corn forage yield, quality and preservation. Agronomy Journal. 94. 3: 559-566.

Dijak, M. A.-Modarres, M.-Hamilton, R. I.-Dwyer, L. M.-Stewart, D. W.-Mather, D. E.-Smith, D. L.: 1999. Leafy reduced-stature maize hybrids to short-season environments. Crop Science. 39: 1100-1110. 
Dwyer, L. M.-Andrews, C.J.-Stewart, D. W.-Ma, B. L.-Dugas, J. A.: 1995. Carbohydrate levels in field-grown leafy and normal maize genotypes. Crop Science. 35: 1020-1027.

Dwyer, L. M.-Stewart, D. W.-Glenn, F.: 1998. Silage yields of Leafy and normal hybrids. [In: Nicolas, S. (ed.) Proc. of 53 ${ }^{\text {rd }}$ Annu. Corn and Sorghum Res. Conf.] Am. Seed. Trade Assoc. Washington, D.C. 193-216.

Hegyi, Zs.-Zsubori, Zs.-Rácz, F.: 2009. Comparative analysis of leafy and non-leafy silage maize hybrids. Acta Agronomica Hungarica. 57. 3: 277-284.

Józsa L.: 1981. Kukoricatermesztés szilázsnak. Mezőgazdasági Kiadó. Budapest.

Menyhért Z.: 1985. A kukoricatermesztés kézikönyve. Mezőgazdasági Kiadó. Budapest.

Modarres, A. M.-Hamilton, R. I.-Dwyer, L. M.-Stewart, D. W.-Dijak, M.-Smith, D. L.: 1997. Leafy reduced-stature maize for short-season environments: Yield and yield components of inbred lines. Euphytica. 97: 129-138.

Pintér, L.-Schmidt,J.-Kelemen, G.-Szabó, J.-Henics, Z.: 1988. Complex evaluation of different corn genotypes for CCM (corn-cob mix) use. Maydica. 33: 283-294.

Shaver, D. L.: 1983. Genetics and breeding of maize with extra leaves above the ear. [In: Wilkinson, D.-Brown, R. (eds.) Proceedings of the 38th Annual Corn and Sorghum Industries Research Conference, Chicago, IL.] Am. Seed Trade Assoc., Washington D.C. 161-180.

Stewart, D. W.-Dwyer, L. M.: 1993. Mathematical characterisation of leaf shape and area of maize hybrids. Crop Science. 39: 422-427.

Sváb J.: 1967. Biometriai módszerek a mezôgazdasági kutatásban. Mezôgazdasági Könyvkiadó Vállalat. Budapest.

Weissbach, F.-Auerbach, H.: 1999. When is maize mature for silage? The demand for higher silage quality and the new maturity classification of silage maize. Mais. 2: 72-77.

A szerzók levelezési címe - Address of the autors:

Tóthné Zsubori Zsuzsanna-Pók István-Hegyi Zsuzsanna

MTA Mezógazdasági Kutatóintézete

Kukoricanemesítési Osztály

Martonvásár

Brunszvik u. 2.

H-2462 